INSIGHTS INTO REGIONAL DEVELOPMENT

ISSN 2669-0195 (online) http://jssidoi.org/IRD/

2021 Volume 3 Number 4 (December)

http://doi.org/10.9770/IRD.2021.3.4(4)
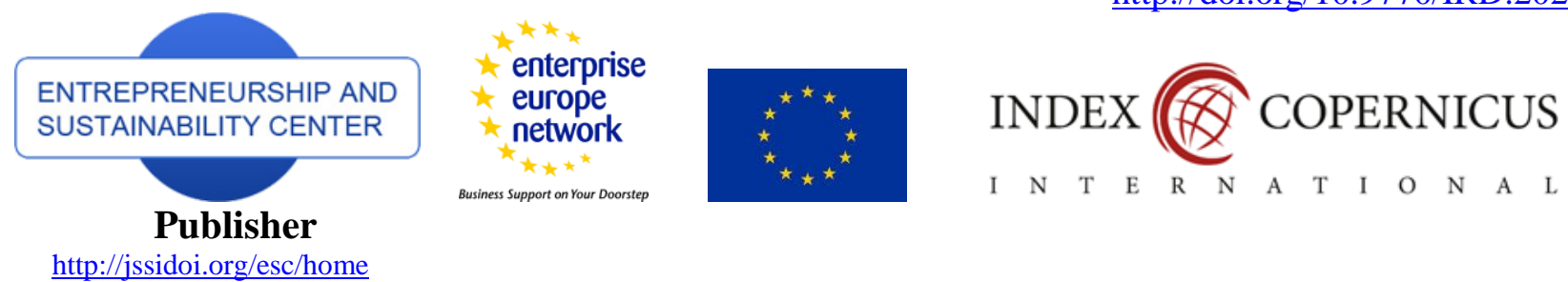

$\begin{array}{lllllllllllll}\text { I } & \mathrm{N} & \mathrm{T} & \mathrm{E} & \mathrm{R} & \mathrm{N} & \mathrm{A} & \mathrm{T} & \mathrm{I} & \mathrm{O} & \mathrm{N} & \mathrm{A} & \mathrm{L}\end{array}$

http://jssidoi.org/esc/home

\title{
PECULIARITIES OF ICT ADOPTION IN NIGERIA
}

\author{
Sunday Olutayo Fakunlec ${ }^{1}$, Bukunmi Kehinde Ajani ${ }^{2}$ \\ ${ }^{1}$ Department of Behavioural Studies, Redeemer's University, Ede, Nigeria \\ ${ }^{2}$ Department of Sociology and Anthropology, Obafemi Awolowo University, Ile-Ife, Nigeria \\ E-mails: ${ }^{1}$ sunnyfak@gmail.com or fakunles@run.edu.ng ; ${ }^{2}$ bukjani5@gmail.com
}

Received 15 August 2021; accepted 25 October 2021; published 30 December 2021

\begin{abstract}
From the vantage point of social change and development, studies have indicated that applying information and communication technology (ICT) in people's daily activities has enabled human beings to amazingly achieve things that were considered unattainable a couple of centuries ago. These remarkable achievements are evident in healthcare system, education, connectivity, economic and religious activities, among others. Studies have further indicated that there is some discrepancy between the extent to which the residents of the advanced countries and developing countries respectively accept ICT use in their daily activities. Hence, the sole objective of this systematic review is to investigate the current position of ICT use by the residents of Nigeria and the socio-cultural, economic, and technical factors that influence the popularity and acceptability of the ICT use in the country. To attain this objective, relevant available previous, mainly indigenous, studies that were published from the year 2015 to the year 2021 were sought and sorted, while the integration of the relevant previous qualitative, quantitative, empirical and theoretical studies were carried out thematically. This study discovered ICT use in tertiary education, maintenance of relationship, complementing healthcare system, ensuring the safety the relatives, religious and economic activities among the residents of the country. The conclusion drawn from this systematic review was that the ICTs use has been widely accepted among Nigerians in their various social activities, however, with challenges posed by several socio-cultural, economic and technical factors.
\end{abstract}

Keywords: ICT use; social activities; socio-cultural factors; ICT challenges; Nigeria

Reference to this paper should be made as follows: Fakunle, S. O., Ajani, B. K. 2021. Peculiarities of ICT adoption in Nigeria. Insights into Regional Development, 3(4), 51-61. http://doi.org/10.9770/IRD.2021.3.4(4)

JEL Classifications: $\mathrm{O} 33$

Additional disciplines: sociology; educology; information and communication, social change

\section{Introduction}

On the basis the timeline that signifies the extent to which people in Nigeria have applied the ICTs in their various social activities, studies have established that the use of the ICTs, in particular mobile phones, personal computers, the Internet, among others, is not new in the country. For instance Ajani and Fakunle (2018) have established that people in the country are accustomed to use of mobile phone, as an ICT, and this technology has influenced the trips on various social activities people embark on in Nigeria. Also, Onyema (2019) have emphasized a number of opportunities embedded in the use of ICTs in imparting knowledge to students in the 


\section{INSIGHTS INTO REGIONAL DEVELOPMENT}

ISSN 2669-0195 (online) http://jssidoi.org/jesi/

2021 Volume 3 Number 4 (December)

http://doi.org/10.9770/IRD.2021.3.4(4)

country. In the same vein, Ajani and Fakunle (2021), Familusi and Ajayi (2019) as well as Imam-Tamim, Zin and Ibrahim (2016) discussed the ICTs use that enabled people in Nigeria to have constant contact with people in other continents and the impacts that the use has on traditional family structures while in Nigeria. Moreover, Muoghalu and Fakunle (2021) as well as Adenuga, Iahad and Miskon (2020) indicated that the ICTs, in particular android mobile phone and the Internet, have also enabled the residents of Nigeria to access health services in various forms without visiting the medical centres. Among the main reasons often cited for the use of these ICTs in people's daily activities are convenience, time saving and enhancement of the quality of service rendered with the use of the ICTs (Ajani and Fakunle, 2021a; Adenuga, Iahad and Miskon, 2020; Chair, 2017; Abdullahi, Ghazali, Awang, Tahir and Ali, 2015). Moreover, Onyema (2019) added that a number of people, in particular the youths simply use the ICTs only to indicate that they are not lagging behind in technology savvy. At a superficial level, the epic perspective suggests that all these studies indicated wide acceptance of application of the ICTs in the social activities of residents of Nigeria. This current study applied the emic perspective to review the available relevant previous indigenous studies to investigate the current position of ICT use by the residents of Nigeria and the socio-cultural and economic factors that influence the popularity and acceptability of the ICT use in the country, and this account for the novelty value of this study.

\section{Theoretical framework}

A number of theorists have developed a set of interrelated assumptions about the acceptance or rejection of an idea, a concept, an object, a particular kind of behaviour and technology. Among these theorists is Everett Rogers (2003). In the $5^{\text {th }}$ Edition of Diffusion of Innovation, Rogers (2003) implied that the diffusion of any innovation (for instance, a new idea) is not complete at once because not everybody accepts an idea at the initial stage it arrives. However, he asserted that the acceptance of a new innovation involves a gradual process and a series of stages where the key actors, which might be individuals, communities, societies, regions or nations, are in different stages of the acceptance. In this study, the innovation refers to the ICTs as these technologies spread from where they are made (for instance, industrialized countries) to another location where they were not readily available (developing countries). According to Rogers (2003), the key actors in different phases of receptivity of an innovation are: the innovators (who readily accept the use of ICTs and even carry out experiments to get more); the early adopters (those that also use the ICTs to accomplish tasks); the early majority (who adopt the ICTs but are not interested in applying the ICTs to accomplish tasks); the late majority (who stick to the conventional ways of doing things and are not comfortable with the ICTs); and the laggards (with the highest percentage of rejecting the use of ICTs). This relevance of this theory in this review manifests in the study objective which is to investigate the current position of ICT use by the residents of Nigeria. However, this study included the review of the socio-cultural, economic and technical factors that influence the popularity and acceptability of the ICT use in the country.

\section{Review procedure and basis}

The activities involved in carrying out this systematic review as guided by the sole purpose of this study began with searching the relevant available previous, mainly indigenous, studies that were published from the year 2015 to the year 2021 via database searching to reduce the influence of time lags and to maintain the recency of these studies. This theoretical study was the integration of relevant previous qualitative, quantitative, empirical and theoretical studies that were carried out thematically. 


\section{INSIGHTS INTO REGIONAL DEVELOPMENT}

ISSN 2669-0195 (online) http://jssidoi.org/jesi/

2021 Volume 3 Number 4 (December)

http://doi.org/10.9770/IRD.2021.3.4(4)

\section{Review of the relevant literature}

\section{a. ICT use: an opportunity to facilitate learning}

Geometric increase in the population of young people signifies need for more schools with needed facilities for smooth learning in Nigeria. Also, the stance of a number of scholars is that the application of the Internet and android phones has lent students a helping hand in their studies in the country (Onyema, 2019; Hejab, Al and Shaidah, 2017; Laidi, 2016; Osubor and Chiemeke, 2015). However, poor economy condition of many developing countries, including Nigeria, coupled with high level of corruption has inhibited the establishment of schools with modern infrastructures to facilitate learning (Niebel, 2018; Kuboye, 2017; Siew, Nor, Nor and Nur, 2017; Zakaria, Fordjour and Afriyie, 2015). These previous indigenous studies have indicated that close examination of the potential roles of incorporating the ICTs use in education could be an alternative to the learners in the country.

Electronic-learning (also known as e-learning) is becoming popularly accepted in Nigeria. Provision of distance learning opportunities emphasizes the importance of e-learning for people residing in the remote areas where opportunities for conventional mode of learning are not readily available. Mobile phones, in particular android types, coupled with the Internet are useful in e-learning (Tossell, Kortum, Shepard, Rahmati, Zhong, 2015). According to Gillwald, Odufuwa and Mothobi (2018), these technological gadgets provide a platform for teacherstudent interaction and relation for learning without meeting face-to-face. Moreover, some of the features of mobile phones that facilitate e-learning include text messaging especially for the students that are nervous and afraid of face-to-face communication (Igyuve, Akilla, Oriola and Agbele, 2018). This feature also enables students to individually share private information with their teachers on the state of their learning process, also, texting has been reportedly identify as one of the fast ways to pass information (Onyema, 2019; Hejab et al., 2017).

The millennials in sub-Saharan Africa have experienced swift changes in technology. For instance, invention and introduction of (android or smart) mobile phones and improved internet facilities have enabled the millennials to get interconnected globally (Muoghalu and Fakunle, 2021). In the same vein, the millennials in Nigeria have experienced increase in virtual (online) interaction with school mates, peers, online study groups and teachers (Laidi, 2016; Osubor and Chiemeke, 2015). This interaction has further facilitated learning, tutoring, sharing and disseminating vital information and conducting exercises or tests in the virtual world. Therefore, in the subSaharan region of Africa in general and Nigeria in particular, learning is not limited to face-to-face interaction that takes place in the classrooms; it has extended to the virtual world.

Studies have explored the ICTs that are peculiar to the sub-Saharan region including Nigeria (Ajani and Fakunle, 2021; Wobodo, 2020; Onyema, 2019; Niebel, 2018; Olaoye and Adebayo, 2017; Laidi, 2016; Zakaria et al., 2015). These studies found that the technologies that are utilized for learning purposes in the region as a whole include computers (both laptops and desktops), iPods, (android) mobile phones with a series of applications on them that facilitate both online and offline learning. However, drawing on the convergence of diverse opinions, theoretical debates and empirical findings of the extant indigenous studies, the most widely accepted technology utilized for educational purpose in the region is (android) mobile phones.

In Nigeria, use of laptops, projectors, sound systems, the Internet facilities to make the teaching more practical and visual for the teachers and more understandable for the students exists; all these have further emphasized the importance of employing technology devices in classroom teaching and learning (Onyema, 2019; Hejab et al., 2017). However, the use of these ICTs, in particular mobile phone, has not been popularly adopted in a number of lower institutions of learning in particular secondary schools in the country (Laidi, 2016). Moreover, some of these portable technology devices are utilized to record audio and capture video which the students could play to revise things they were taught after the lecture at their leisure time (Tossell et al., 2015). Studies have established 


\section{INSIGHTS INTO REGIONAL DEVELOPMENT}

ISSN 2669-0195 (online) http://jssidoi.org/jesi/

2021 Volume 3 Number 4 (December)

http://doi.org/10.9770/IRD.2021.3.4(4)

that teachers of the higher institutions of learning in the country are able to give assignment that in most instances necessitates surfing the web in search of e-books, online journals and other materials that could be assessed only on the Internet (Onyema, 2019; Osubor and Chiemeke, 2015; Zakaria et al., 2015). However, this has not extended to secondary students in the country.

\section{b. Reasons for the popularity of ICT for learning}

A closer examination on the reasons behind popular acceptance of mobile phone technology for learning in the region indicates that this device has low cost (however, the cost varies in relation to the brand and type of the phone), various operating systems that accommodate a calculator, camera, audio, video and Internet facilities, calendar among others. Moreover, mobile phones' ability to accommodate various online and offline applications such as the Facebook, WhatsApp, dictionaries, word games, Computer-Based Tests, among others, that could be use while walking from one place to another anytime anywhere and portability, as a result of the weight and size, of mobile phone further lends credence to the devices' popular acceptance.

\section{c. ICT and connectivity}

The functions and features of many android mobile phones have generated significant alterations in some of the ways people in sub-Sahara West Africa conduct their daily activities (Ajani and Fakunle, 2021b; Cosmas, Nwankwo, Kanyangale and Okechukwu, 2019; Ajani and Fakunle, 2018; Rahman and Zhang, 2017; Omotayo, 2016; Imam-Tamim, Zin and Ibrahim, 2016). For instance, in the early first quarters of the year 2020, the outbreak of Corona Virus Disease of 2019 (otherwise known as COVID-19) that is transmissible through droplets from the infected respiratory organ of the disease carrier has prompted medical experts to recommend avoiding a close gathering of people and maintaining "social distancing"- a term that refers to keeping six feet distance between two people to avoid the spread of the disease (Muoghalu and Fakunle, 2021). This recommendation has generated an increase in the popularity of conducting video conference through the (android) mobile phones in the region (Wobodo, 2020). This mobile phone feature makes the means of communication and sharing information whereby people are able to maintain eye-to-eye contact available.

Moreover, during the COVID-19 pandemic, the use of android phones and laptops for online classes were suggested as a replacement for holding face-to-face classes, in particular in the higher institutions of learning in Nigeria just as in more advanced countries (Babalola, Anayo and Itoya, 2021; Bokolo, 2020). However, this was not executed in the larger part of the country (Onyema, 2019). Systematic review of extant previous studies has indicated the some of probable reasons cited for the inability to replace holding face-to-face classes with online classes include poor network service delivery by the service provider, costs of sophisticated mobile phones and browsing data subscription, complaints from some students that having online classes affects their level of understanding, theft and technical faults of the students' mobile phones, poor technical know-how of the (smart) mobile phones that generate their underutilization.

\section{d. Poor receptiveness of ICT use in learning}

In spite of the popular acceptance that use of technology, in particular smartphones, enhances learning; another school of thought has held an antithetical view. Studies have established that the more the students of higher institutions of learning utilize mobile phone in the educational activities, the lower their academic performance (Hejab et al., 2017; Laidi, 2016; Aregbesola and Asani, 2015; Osubor and Chiemeke, 2015; Tossell, et al., 2015). Hence, these scholars advocate reassessing adopting mobile phones as a tool to facilitate learning among students in tertiary institution. In the same vein, in spite of a number of opportunities in education that mobile phone use intervention tends to generate, use of mobile phones in high schools, popularly known as secondary schools, in Nigeria has not gained popular acceptance. These previous studies have established that authorities of these institutions of learning cited mobile phone abuse and inappropriate phone etiquette among students. 


\section{INSIGHTS INTO REGIONAL DEVELOPMENT}

ISSN 2669-0195 (online) http://jssidoi.org/jesi/

2021 Volume 3 Number 4 (December)

http://doi.org/10.9770/IRD.2021.3.4(4)

Moreover, Siew, et al. (2017) and Laidi (2016) added that the introduction of mobile phone use among secondary schools students generates loss of full concentration on the lecture taking place in the class for them. These scholars cited that the Apps for entertainment and social media such as Facebook, WhatsApp, Youtube, Instagram among others, on (android) mobile phone divert the attention of these students away from their lectures as a number of these students fail to observe mobile phone use off-limit domains. The poor concentration of the students generates their low level of understanding of what they are taught in class and poor academic performance at large. As a result of negative effects of mobile phone use on secondary school students' academic performance, school authorities have resorted to warning, confiscation and destruction of the mobile phones sighted among the students during their lectures (Onyema, 2019). In addition, another factor identified is poor receptivity of the governments and schools in the region to venture into technology resources to facilitate learning in the classroom (Aregbesola and Asani, 2015).

\section{e. Overview of ICTs use and economic opportunities in Nigeria}

Also, advancement of technology has led to the invention of fax machines, photocopier, mobile phone, laptops and the Internet. These technology devices have gain acceptance as among the tools that promote selfemployment in the country (Omoneye, 2019; Gabriel, Ogbiugwe and Ahiauzu, 2016; Agwu and Murray, 2015). A number of the self-employed utilize these devices to render services to their customers and to access useful information that could promote their businesses and to maintain seller-customer relationship by contacting their customers about their products (Okundaye, Fan and Dwyer, 2019). These devices have generally promoted their daily business activities. A number of unemployed youths, both males and females, are able to become selfemployed by getting involved in business activities actuated by the Information Communication Technologies (Ajani and Fakunle, 2021a; Okundaye et al., 2019; Abdullahi, et al., 2015). Such business activities include sales of data for browsing and recharge cards, sales of mobile phones, phone accessories, computers and computer accessories. Ajani and Fakunle (2021a) further portray the impact of the ICTs in engendering gender equality in the region.

The Internet is one of the components of technology that have introduced new services in the country. For instance, the Internet has generated online shopping which in turn has bred the proliferation of a number of business centres (such as Jumia, Konga, Slot, Kara, Parktel Online, Dealdey, Kaymu, among others) that provide online services. Online shopping has further boosted the economy in the region. Technology has generated a number of advantages for the people in the country through online shopping. For instance, reports about online shopping show that online shoppers in the region found it user-friendly and it provides the users the means of making their choices at their convenient time and location (Cosmas et al., 2019). Moreover, Olaoye and Adebayo (2017) found that ICT has enabled the introduction of cashless policy into the country which tends to generate a decrease in the workload of workers that deals with counting banknotes, however, with several challenges in particular, poor network service delivery.

Teleconference, telecommuting and tele-working promote flexibility of work and working arrangements. However, in the country, teleconference and tele-working to promote business activities have not been popularly accepted as people still have a greater preference for face-to-face interaction (Bokolo, 2020; Ajani and Fakunle, 2018). This preference is as a result of the challenges that people face in the Internet use such as the cost incurred to access the Internet, poor network service delivery, and the cost of sophisticated means of communication that has suitable applications for teleconferencing such as laptops and suitable smartphones (Ajani and Fakunle, 2021a; Ajani Fakunle, 2018). 


\section{INSIGHTS INTO REGIONAL DEVELOPMENT}

ISSN 2669-0195 (online) http://jssidoi.org/jesi/

2021 Volume 3 Number 4 (December)

http://doi.org/10.9770/IRD.2021.3.4(4)

\section{f. ICTs use and religion}

The richness of the country in culture and tradition manifests in the religious activities and other social engagements of the people living in the region. The advent of the Information and Communication Technology in the country has prompted studies on the influence of mobile phone, laptops and the Internet use on social activities of the residents of the region (Ajani and Fakunle, 2021a; Muoghalu and Fakunle, 2021; Ajani and Fakunle, 2018; Tob-Ogu, Kumar and Cullen, 2018). In contemporary period, various religions in the world have accommodated the use of ICTs in their practices and this is attainable in the region as well (Wobodo, 2020). For instance, larger percentage of the Moslems, Christians and traditional religion worshippers own mobile phones, laptop or desktop computer and access the Internet through these devices in Nigeria (Omotayo, 2016). This ownership distribution is an indication that the three main religions that exist in the country embraced various aspects of modern technology. Therefore, ICTs have become a part of the valuable religious tools and this attests to the assertion that a number of religions in the contemporary era do not preach against ICTs use.

Technology devices, in particular android phones and laptops, accommodate various Applications (for Bible, Quran, Hymn, Calendar, among others) that are used in religious activities. However, there are people that still opined that replacement or substituting The Holy Books (The Bible and Quran in Nigeria's case) with the Apps that contains the softcopy of these Books on computers and android phones translates to an act of impropriety, hence they considered it sacrilege. In contrast, a large number of people in the country have adopted the use of these Apps in their activities; hence, both religion and advance of technology tend to complement each other in the location. Moreover, people in the region utilized the Apps on their mobile phone to listen to preaching and religious songs. Also, as a proactive measure to curb the increase in transmission of COVID-2019, governments of the countries in the region declared total lockdown to restrict movement and physical gathering, and to avoid physical contact among people. Therefore, worshippers in the region resorted to video conferencing and virtual meetings to maintain eye-to-eye contact and to conduct their services and other religious activities (Amadi-Nche, 2021).

The ICTs have generated online services that further promote centralization of tradition, culture and mode of worship for worshippers that belong to the same denomination in the region. This centralization further tends to promote oneness among the congregation as they all listen to the same sermons, and are open to the same teachings and doctrines. In a part of the region, Ajani and Fakunle (2021a) established that mobile phone use has generated more trips on religious activities for women than for men, while both men and women have accessed more information about their religious programmes and this results in increased participation.

\section{g. ICT use for safety}

Seeking help in any state of emergency has justified mobile phone ownership for a number of people in the region. For instance, people in the region have expressed that mobile phones have offered an opportunity to get an instant connection between them and those that would help them in the event of a need for help or assistance. However, unlike in advanced countries where family members use Global Positioning System (GPS) based services to track one another for protection (Auyo, Idris, Mato, Ibrahim, 2020; Ashara, Saleh, Hassan and Kaura, 2020; Kemi and Happiness, 2016), in the region, these services are used underutilized as they are mainly used by the security agencies to track crime suspects and criminals while not quite a large number of people employ the services to track their property such as vehicles in the stead of family members (Abulude, Akinnusotu and Adeyemi, 2015).

\section{h. ICT and healthcare}

Muoghalu and Fakunle (2021) observed that steady rise in the number of the residents of Nigeria and low number of the qualified medical practitioners that are accessible, coupled with the monetary cost of healthcare services has enabled telemedicine to gain popularity in the country. According to Manyati and Mutsau (2020) as well as 


\section{INSIGHTS INTO REGIONAL DEVELOPMENT}

ISSN 2669-0195 (online) http://jssidoi.org/jesi/

2021 Volume 3 Number 4 (December)

http://doi.org/10.9770/IRD.2021.3.4(4)

Ibekwe and Fasunla, (2020), telemedicine, a concept that denotes provision of healthcare services via the Internet, has helped in bridging the gap between the reality and appropriate proportion of heath service delivery. Also, Adenuga, Iahad and Miskon (2020) added that the Internet as an ICT has provided a platform for people in the country to communicate and share vital information about their health condition with the medical experts, and to seek advice from knowledgeable people about a particular kind of disease and how such a disease is partially managed or totally controlled. Adenuga, Iahad, Miskon (2017) further added that the ICT has enabled medical experts from the remote places both in and outside the country to render humanitarian services to the masses by posting health-related information about patient self-care and the outbreak of a particular disease and the measures to curtail the pandemic.

One of the main factors that characterize the majority of the developing countries is poverty. The majority of the financially challenged people are denied of the access to quality health service delivery in the country (Idoga, Toycan, Nadiri and Çelebi, 2019). Governments in Nigeria at different levels have made efforts to ensure that the masses are able to gain easy access to quality health services; therefore, several programmes are initiated. Among the programmes is National Health Insurance Scheme (NHIS) where people have to register with forty-five thousand Naira, which is equivalent to one hundred US Dollars as of July 2021, so that the people that have registered for this scheme are only obliged to pay just ten percent of the total cost of the medical service they get. However, one of the major demerits of the scheme is that a number of people in the country live below one US Dollars per day coupled with the present astronomical increase in the price of goods translates to a concomitant increase in the inability of this set of people to enjoy this scheme. In the other way, Muoghalu and Fakunle (2021) noticed that the use of the Internet for enlightenment and dissemination of health-related issues and essential information about enhancing public health tends to generate prevention of illness in the body and drastic reduction in the cost maintaining people's wellbeing. Moreover, these scholars noted that such medical costs as medical consultancy fee, among others are averted with the use the ICTs. Also, Ajani and Fakunle (2018) found that people in the country utilized mobile phone, as an ICT, to call on the relatives and medical experts to seek help in when the need arrives.

$i$. The Challenges of Information Technology in Nigeria: Indigenous studies have uncovered multifarious challenges people in Nigeria encounter in using the Internet and mobile phones. Some of these challenges include:

\section{(i) Economic barrier}

One major problem that characterizes the majority of the developing countries, including Nigeria is high level of poverty among people (Bokolo, 2020; Idoga, et al., 2019; Okundaye, et al., 2019). Therefore, poverty has compounded the challenges that people encounter in possessing android phones or personal computers and accessing the Internet. For instance, a large number of residents of the region are faced with the challenge of covering the monetary costs of owning these gadgets and high tariff of accessing the Internet charged by the telecommunication service providers (Muoghalu and Fakunle, 2021; Igyuve et al., 2018).

\section{(ii) Poor network service delivery by telecommunication service providers}

Poor network coverage in the service delivery of telecommunication service providers in the country limits the access that the Internet users have to surf the Internet. People in large cities, towns and, in general, urban centres have greater access to use of these ICTs as a result of the availability of the facilities such as electricity, network coverage, among others in these centres. However, people such as farmers and petty traders in rural areas of the region are able to use mobile phones and the Internet only where the network service covers, the coverage in most instances is limited to urban areas or where there is high population of people (Muoghalu and Fakunle, 2021; Agwu and Murray, 2015). Hence, the unavailability of the network service constitutes a barrier that prevents these people from using mobile phones or accessing information via the Internet at their workplaces. 


\section{INSIGHTS INTO REGIONAL DEVELOPMENT}

ISSN 2669-0195 (online) http://jssidoi.org/jesi/

2021 Volume 3 Number 4 (December)

http://doi.org/10.9770/IRD.2021.3.4(4)

\section{(iii) Theft and cyber-crime}

As a result of high crime rate, a number of mobile phone users in the region have cited losing their phones through theft and this has denied them of the benefits that they could have gained from using the phones (Ajani and Fakunle, 2018). These scholars, moreover, found that more women reported phone theft than men in southwestern part of Nigeria. Also, reports on cyber-crime have indicated that people in the region are not free from being innocent dupes and victims of fraudulent acts via mobile phones (Asongu and Le, 2017).

\section{(iv) Technical-know-how and underutilization}

Inability of phone-users to understand the language that the phone-makers used to identify the icons and directions to operate and fully utilize this gadget is another barrier (Ajani and Fakunle, 2018; Chair, 2017). The descriptions on computers and most of the mobile phones supplied to the country are largely in foreign languages and only the literate are suggested to be able to understand and fully utilize the functions on these technology gadgets. However, some phone-makers have programmed different local languages on their brands, only the literate are still able to understand the functions on these gadgets. Moreover, a number of phone users are mere concerned with making and receiving phone calls and messages on their phones while other functions are neglected or the users are not aware of other uses.

\section{(v) Technical faults}

Frequent technical fault of these technology gadgets, coupled with extant high level of poverty, is another barrier that the residents of the region face (Chair, 2017; Gabriel et al., 2016). The maintenance costs of technology gadgets have discouraged a number of people in the region from harnessing the benefits accrued from using sophisticated mobile phone and computers.

\section{(vi) Unfavourable cultural practices and social norms}

In several parts of the region, there are extant social norms and cultural practices that subtly constitute underlain barriers to using modern technology gadgets to the fullest benefits. In the region, in spite of the concerted efforts of government and non-governmental organisations to curb gender inequality, there are several cultural factors that subtly limit women economic empowerment and access to education (Mumporezea and Prieler, 2017; Goswami and Dutta, 2016; Motilewa, Onakoya and Oke, 2015). These factors include the widely-held belief that women are mainly to prepare food, nurse children and take care of their home; therefore, women are believed to be subjected to attaining low level of formal education and having access to only the resources their husbands provide for them. Women low level of literacy and poor economic power translate to their poor accessibility to the Information Technology.

\section{Conclusions and prospects for future research}

The conclusion drawn from this systematic review was that ICTs use has been widely accepted among Nigerians in their various social activities, however, with several challenges. These challenges are signals for the network service providers to devise means of improving their service delivery and to expand their network coverage, for the security agencies to devise means of curbing mobile phone theft, for the authorities of the high schools to incorporate ICTs use in imparting knowledge on students and for the policy-makers to create the environment that favours the use of these ICTs by the masses in the country. The main limitation of this systematic review, however, was envisaged to manifest in the content validity of the employed previous studies pertaining to the ICT use by the masses in Nigeria as this study absolutely hinged on them. Therefore, this limitation advocated a similar but empirical study. 


\section{INSIGHTS INTO REGIONAL DEVELOPMENT}

ISSN 2669-0195 (online) http://jssidoi.org/jesi/

2021 Volume 3 Number 4 (December)

http://doi.org/10.9770/IRD.2021.3.4(4)

\section{References}

Abdullahi, M., Ghazali, P., Awang, Z., Tahir, I., Ali, N. 2015. The effect of finance, infrastructure and training on the performance of small and medium scale enterprises (SMEs) in Nigeria. International Journal of Business and Technopreneurship, 5(3), 421-452

Abulude, F. O., Akinnusotu, A., Adeyemi, A. 2015. Global positioning system and its wide applications. Continental Journal of Information Technology, 9(1), 22-32. doi:10.5707/cjit.2015.9.1.22.32

Adenuga, K. I., Iahad, N. A., Miskon, S. 2020. Telemedicine System: Service Adoption and Implementation Issues in Nigeria. Indian Journal of Science and Technology, 13, 1321-1327.

Adenuga, K. I., Iahad, N. A., Miskon, S. 2017. Towards reinforcing telemedicine adoption amongst clinicians in Nigeria. International Journal of Medical Informatics, 104, 84-96.

Adenuga, K. I., Iahad, N. A., Miskon, S. 2020. Telemedicine system: Service adoption and implementation issues in Nigeria. Indian Journal of Science and Technology, 13, 1321-1327.

Agwu, E. M., Murray, P. J. 2015. Empirical study of barriers to electronic commerce uptake by SMEs in developing economies. International Journal of Innovation in the Digital Economy, 6(2), 1-19. doi: 10.4018/ijide.2015040101

Ajani, O. A., Fakunle, S. O. 2021a. Gender differential in mobile phone use and travel behaviour. Discovery, 2021, 57(306), 519-529

Ajani, O. A., Fakunle, S. O. 2021b. Globalisation and Trends of Changes in Family Institution in Nigerian Society. American International Journal of Supply Chain Management, 2(1), 37-45

Ajani O. A., Fakunle S. O. 2018. Mobile phone use and travel behaviour of adult residents Ile-Ife, South-western Nigeria. Research on Humanities and Social Sciences, 8(14), 71-77.

Amadi-Nche, C. 2021. ICT: A coping strategy by Nigerian churches amidst Covid-19 pandemic. International Institute of Academic Research and Development, 7(1), 13-18

Aregbesola, T. S., Asani, E. O. 2015. Factors influencing the adoption of smartphones by university students: a cross-border approach. African Journal of Computing and ICT, 8 (1).

Ashara, A. H., Saleh, S., Hassan, U., Kaura, M. J. 2020. Traffic management system in Abuja city center, using Geographic Information Systems (GIS) and Global Positioning System (GPS). A case study of FCT, Nigeria. Journal of Physics: Conference Series, 1529052068

Asongu, S. A., Le, S. 2017. Technological forecasting and social change enhancing ICT for inclusive human development in Sub-Saharan Africa. Technological Forecasting and Social Change, 118(5), 44-54. doi:10.1016/j.techfore.2017.01.026

Auyo, S. G. Idris A., Mato, I., Ibrahim, A. A. 2020. A Review on the Use of ICT as a means of Security within Tertiary Institutions in Nigeria. Dutse Journal of Pure and Applied Sciences (DUJOPAS), 6(4), 76-81, 2020

Babalola, D., Anayo, M., Itoya, D. A. 2021. Telehealth during COVID-19: Why sub-Saharan Africa is yet to log-in to virtual healthcare. Medical Science, 8(1), 46-55.

Bokolo, A. J. 2020. Use of telemedicine and virtual care for remote treatment in response to COVID-19 pandemic. International Journal of Medical System, 44(7), 132.

Chair, C. 2017. Internet use barriers and user strategies: perspectives from Kenya, Nigeria, South Africa and Rwanda. Available at: https://researchictafrica.net/2017/03/15/Internet-use-barriers-and-user-strategies-perspectives-from-kenya-nigeria-south-africa-andrwanda// (accessed March 2021).

Cosmas, A. Nwankwo, C., Kanyangale, M., Okechukwu, J. A. 2019. Online shopping industry and its consumers in Nigeria. Journal of Economics Management and Trade, 23(3), 1-12. doi: 10.9734/JEMT/2019/v24i330165.

Familusi, O. O., Ajayi, D. S. 2019. Effects of globalization on Yoruba family values. Nigerian Journal of Applied Psychology, 21(1), 207227 


\section{INSIGHTS INTO REGIONAL DEVELOPMENT}

ISSN 2669-0195 (online) http://jssidoi.org/jesi/

2021 Volume 3 Number 4 (December)

http://doi.org/10.9770/IRD.2021.3.4(4)

Gabriel, J. M. O. Ogbiugwe, T. D. Ahiauzu, L. U. 2016. Online shopping system in Nigeria: Evolution, trend, and prospects. Asian Research Journal of Arts \& Social Sciences, 1(4), 1-7. doi: 10.9734/ARJASS/2016/29170

Gillwald, A., Odufuwa, F. Mothobi, O. 2018. The state of ICT in Nigeria. Cape Town. South Africa. Research ICT Africa. https://researchictafrica.net/after-access-nigeria-state-of-ict-2017

Goswami, A., Dutta, S. 2016. Gender difference in technology usage- A literature review. Open Journal of Business and Management, 4, 51-59. doi: 10.4236/ojbm.2016.41006

Hejab, M. Al, F., Shaidah, J. 2017. The use and effects of smartphones in higher education. IJIM, 11(6),106-111.

Ibekwe, T. S., Fasunla, A. J. 2020. Telemedicine in otorhinolaryngological practice during COVID-19 pandemic. Nigerian Medical Journal, 61, 111-113.

Idoga, P. E., Toycan, M., Nadiri, H., Çelebi, E. 2019. Assessing factors militating against the acceptance and successful implementation of a cloud based health center from the healthcare professionals perspective: A survey of hospitals in Benue State, North-central Nigeria. BMC Medical Informatics and Decision Making, 19, 34.

Igyuve, A. I, Akilla, O. M., O. M. Oriola, Agbele, J. D. 2018. Smartphone adoption in Nigeria: Issues and discourse. Saudi Journal of Humanities and Social Sciences (SJHSS), 3(1A), 11-20. doi:10.21276/sjhss.2018.3.1.3

Imam-Tamim, M. K., Zin, N. M., Ibrahim, N. 2016. Impact of globalisation on domestic family law: Multi-tiered marriage in Nigeria as a case study. The Journal of Legal Pluralism and Unofficial Law, 48(2), 256-272.

Kemi, A. O., Happiness, K. P. 2016. The role of Information Technology in national security: A case study of Nigeria International Journal of Mathematics and Computer Science, 10(8), 45-54.

Kuboye, B. M. 2017. Evaluation of broadband network performance in Nigeria. International Journal of Communications, Network and System Sciences, 10(9), 199

Laidi, O. F. 2016. College students and smartphone ownership: symbolic meanings and smartphone consumption among Nigerian Students. AUDC, $10(1), 17-31$

Manyati, T. K., Mutsau, M. 2020. Exploring the effectiveness of telehealth interventions for diagnosis, contact tracing and care of Corona Virus Disease of 2019 (COVID19) patients in sub-Saharan Africa: A rapid review. Health and Technology, 342(21), 11, $341-348$. doi: $10.1007 / \mathrm{s} 12553-020-00485-8$

Motilewa, B. D., Onakoya, O. A., Oke, A. O. 2015. ICT and gender specific challenges faced by female entrepreneurs in Nigeria. International Journal of Business and Social Science; 6(3), 97-105

Mumporezea, N., Prieler, M. 2017. Gender digital divide in Rwanda: A qualitative analysis of socioeconomic factors. Telematics and Informatics, 34(7), 1285-1293. doi: 10.1016/j.tele.2017.05.014

Muoghalu, C. O., Fakunle, S. O. 2021. Socio-cultural binoculars view of telemedicine in sub-Saharan Africa: Potency, prospect, defect and danger. American International Journal of Biology and Life Sciences, 3(1), 18-27.

Niebel, T. 2018. ICT and economic growth. Comparing developing, emerging and developed countries. World Development, 104, 197-211. doi: 10.1016/j.worlddev.2017.11.024

Okundaye, K., Fan, S., Dwyer, R. 2019. Impact of information and communication technology in Nigerian small-to medium-sized enterprises. Journal of Economics, Finance and Administrative Science, 24(47), 29-46. doi: 10.1108/JEFAS-08-2018-0086

Olaoye, F. O., Adebayo, I. A. 2017. Empirical evaluation of government cashless policy and accountants' workload in selected higher institutions in Ekiti state, Nigeria abstract. International Journal of Innovative Research and Development, 6(10), 1-6

Omoneye, O. 2019. Online shopping and customers' satisfaction in Lagos State, Nigeria. American Journal of Business Management, 9(6), doi: 10.4236/aijbm.2019.96095 


\section{INSIGHTS INTO REGIONAL DEVELOPMENT}

ISSN 2669-0195 (online) http://jssidoi.org/jesi/

2021 Volume 3 Number 4 (December)

http://doi.org/10.9770/IRD.2021.3.4(4)

Omotayo, F. O. 2016. Adoption and use of information and communication technologies by Pentecostal churches in Ibadan, Nigeria. Journal of Librarianship and Information Science, 49(2), 22-233. doi: 10.1177/0961000616662517

Onyema, E. M. 2019. Opportunities and challenges of the use of mobile phone technology in teaching and learning in Nigeria - A review. International Journal of Research in Engineering and Innovation (IJREI), 3(6), 352-358. doi: 10.36037/IJREI.2019.3601

Osubor, V. O., Chiemeke, S. C. 2015. The impacts of information culture on e-learning innovation adoption in learning institutions in Nigeria. African Journal of Computing and ICT, 8(1), 17-26

Rahman, K. M. A., Zhang, D. 2017. Globalization and family values: Eroding trends. International Journal of Social and Administrative Sciences, Asian Economic and Social Society, 2(2), 63-74.

Rogers, E. M. 2003. Diffusion of innovations (5th Edition). New York. The Free Press.

Siew, F. N. G, Nor, S. I. C. H., Nor, H. M. N., Nur, A. A. M. 2017. The relationship between Smartphone use and academic performance: A case of students in a Malaysian tertiary institution. Malaysian Online Journal of Educational Technology, 5(4)

Tob-Ogu, A., Kumar, N., Cullen, J. 2018. ICT adoption in road freight transport in Nigeria-A case study of the petroleum downstream sector. Technological Forecasting and Social Change, 131, 240-252. doi: 10.1016/j.techfore.2017.09.021s

Tossell, C.C., Kortum, P., Shepard, C., Rahmati, A., Zhong, L. 2015. You can lead a horse to water but you cannot make him learn: Smartphone use in higher education. British Journal of Educational Technology, 46, 713-724

Wobodo J. J. 2020. The church utility of ICTs in Nigeria amid Covid-19 global pandemic. Saipential Global Journal of Arts, Humanities and Development Studies (SGOJAHDS), 3(3), 279-287

Zakaria, I.M., Fordjour, K. A., Afriyie, K. R. 2015. Use of mobile phones to support coursework: Evidence from Wa Polytechnic, Ghana. GJDS, 12(1\&2), 195-207.

Sunday FAKUNLE holds the post of Teaching Assistant at Department of Behavioural Studies, Redeemer's University, Nigeria. With substantial progress, he is currently doing his PhD in Sociology and Anthropology, specializing in Public health, Social Change and Development in African Communities, in Obafemi Awolowo University, Nigeria. He worked as an online Sociology instructor in OAU Centre for Distance Learning, Nigeria.

ORCID ID: orcid.org/0000-0002-0053-0082

Bukunmi AJANI is a recent graduate of Sociology and Anthropology, Obafemi Awolowo University, Ile-Ife, Nigeria. Her research interest lies in socio-cultural anthropology, visual cultural and in exploring the lived experiences of indigenous communities in sub-Saharan Africa.

ORCID ID: orcid.org/0000-0002-3358-890X

Make your research more visible, join the Twitter account of INSIGHTS INTO REGIONAL DEVELOPMENT: @ IntoInsights

Copyright (C) 2021 by author(s) and VsI Entrepreneurship and Sustainability Center

This work is licensed under the Creative Commons Attribution International License (CC BY).

http://creativecommons.org/licenses/by/4.0/

c) (i) Open Access 